\title{
Re-engineering the Building Permits Acquisition Processing to Control the Development of Unauthorized Structures in Ghanaian Communities
}

\author{
Stephen Agyeman, Sampson Assiamah, Herbert Abeka \\ Sunyani Polytechnic, Sunyani, Ghana
}

\begin{abstract}
The unauthorized structural developments in Ghanaian conurbations are on the ascendancy as developers disregard building regulations or felt frustrated by the existing bureaucratic delays in the acquisition of building permits. The existing process has not effectively dealt with the numerous permit issuing challenges in the building construction industry for sustainable national development. The paper sought to come up with an alternative processing approach to fast track the decision making process at the point of granting the permit through the use of information communication technology (ICT) and geographic information system (GIS). To achieve this objective, existing data were gathered and analyzed to get a clear understanding of how the work processes currently operate within permit agencies in Ghana. Also, some selected Metropolitan, Municipal, Districts, and Lands Commission offices were visited to obtained stakeholders' qualitative assessments of the existing process to assist in identifying process areas of key customer concern. Lastly, process flow charts were created to display the entire process in a logical sequence of events from beginning to end. Both “As-Is” and “To-Be” process charts were then produced in Ghanaian context. Advanced systems in developed countries like United States, Hong Kong, and Singapore were used as a baseline to redesign the existing building permit processing in Ghana. The strengths, weaknesses opportunities, and threats (SWOT) analyses of the reviewed system were done. The paper proposed a central database management system (one-stop shop) connecting all the agencies involved in the building permit processing where any application could be worked on by the appropriate agency.
\end{abstract}

Keywords: building permit, acquisition processing, unauthorized structures, ICT, GIS, one-stop shop

\section{Introduction}

Building permit serves as a green light in any land development. Meanwhile, land development has been the principal evidence of an economical valor of many nations in recent times due to architectural innovations and contemporary trends. As such, any nation without consistent and legal framework will be deficient of infrastructural splendor (Government of Ghana, 2008; Hammah, 2010). Generally, the new construction must be inspected during construction and after completion to ensure compliance with national, regional, and local

Stephen Agyeman, lecturer, Department of Civil Engineering, Sunyani Polytechnic, Sunyani, Ghana.

Sampson Assiamah, lecturer, Department of Building Technology, Sunyani Polytechnic, Sunyani, Ghana.

Herbert Abeka, lecturer, Department of Civil Engineering, Sunyani Polytechnic, Sunyani, Ghana.

Correspondence concerning this article should be addressed to Stephen Agyeman, Department of Civil Engineering, Sunyani Polytechnic, P.O. Box 206, Sunyani, Brong Ahafo Region, Ghana. 
building codes and that they are safe and suitable to the environment. Failing to obtain a permit can result in significant fines and penalties, and even demolition of informal construction (World Bank, 2013a). The recent demolitions in New Fadamer (known as Sodom and Gomorrea), Agyei Kwadow in Accra, Adesheman in Kumasi, and similar occurrences in other parts of the country are typical examples.

One requires a building permit and development permit in Ghana before undertaking any building development project. The National Building Regulation, 1996-L. I. in 1630 also stipulates that building on lands without proper land title certificate is unlawful (Government of Ghana, 1996). Therefore, unauthorized structures can be termed as unapproved scheme development (buildings without permits, buildings within the right of way, and any development that has encroached public open and conserved spaces).

In 2007, Ghana New Agency reported that, Parliament and Cabinet have expressed grave concern at the growing laxity in the enforcement of planning and building regulations by MMDAs (Metropolitan, Municipal, and District Assemblies) (GNA, 14 February 2007). These bodies have therefore tasked experts to search for measures to curtail the intriguing situation (Hammah, 2010). A workshop to review processes and procedures for granting building and development permits by the Town and Country Planning Department under the Land Administration Project (LAP) was held in Accra on July 28, 2008 by 38 planners and works' engineers of MMDAs recommended the following:

(1) Shortening the time period for granting permits.

(2) Reducing the number of signatories needed for permits.

(3) Reviewing the law that makes title clearance of a requisite for building permits.

(4) Developing a single system for granting permits in the country.

(5) Frequent holding of meetings to approve permits.

From 2007 to date, there is no sober effort by Parliament, Cabinet, and MMDAs to avert these challenges (Freiku, 2009). However, in Hong Kong, duration for processing of building permit has been reduced to 66 days, using seven procedures and ranked the first while Ghana ranked 151th in the world with processing duration of 220 days and 18 procedures for building permit processing (World Bank \& IFC, 2012). Ghana's position is not too attractive for potential investors. Even though, the Land Administration Project (LAP) was established to hasten the processing of land services, processing of building permits has not seen much improvement. The duration for the processing has the tendency to put prospective developers off thereby increasing the number of informal structures (Oppong \& Yeboah, 2013). In the USA where construction permit application goes through 19 procedures, it only lasts for 40 days while in Ghana, an application goes through 18 procedures and yet lasts for 220 days. Other parts of the country apart from the capital city could go as long as two years (Agyeman, Asiedu, \& Abeka, 2015; Kpamma \& Adjei-Kumi, 2013; Quartey, 2011).

In relation to recent works done by government's agencies to reduce the duration for processing permits, nothing concrete has been achieved. Because the existing system of processing permits is process oriented, it frustrates prospective developers and serves as impetus for the construction of illegal structures. Unless the process is made more efficient, there will continue to be needless delays and increased frustration with the system. There is therefore the need to reengineer the existing process to reduce the duration for acquiring building permits in Ghana. In view of this, the paper seeks to come up with reengineered system of processing building permit applications that can reduce the existing duration, the number of procedures and also make the permit processing client oriented. In addition, this will reduce the risk, time, travel, and delay caused by having to visit several agencies in order to complete the building permit application. 
The rest of the paper is structured as follows: a literature review section which explored strategies employed to make processing easier in developed countries, permit processing related systems and the Ghanaian situation of unauthorized structural development; a methodology section which investigated the "As-Is" and "To-Be" permited processing situations and proposed a revised system in the results and discussion sections; lastly, SWOT analyses were done on the reviewed system and conclusions drawn based on research findings.

\section{Literature Review}

\section{Strategies Employed to Make Processing Easier}

Using one-stop shops to improve coordination. Before a building plan is approved, appropriate clearances are needed to ensure quality and safety (Agyeman et al., 2015). Several agencies are often involved. To prevent overlap and ensure efficiency, many economies have opted to put the agencies in one location. These one-stop shops improve the organization of the review process-not by reducing the number of checks needed but by better coordinating the efforts of different agencies. In that way, more resources can be devoted to safety checks rather than to paperwork. There are different ways to organize a one-stop shop. In Paraguay, authorities moved professionals from seven municipal departments into a single unit. Table 1 shows measures that some countries took in 2009 and 2010 to improve their construction permits acquisition processes.

Table 1

Who Made Dealing With Construction Permits Easier in 2009/10 and What They Did?

\begin{tabular}{|l|l|l|}
\hline Feature & Country(s) & Some highlights \\
\hline $\begin{array}{l}\text { Reduced time for processing } \\
\text { permit applications. }\end{array}$ & $\begin{array}{l}\text { Benin, Burkina Faso, Democratic Republic of } \\
\text { Congo, Croatia, Hungary, Kazakhstan, Mexico, } \\
\text { Peru, Romania, Rwanda, Sierra Leone }\end{array}$ & $\begin{array}{l}\text { In Benin, a new commission to process building } \\
\text { permit applications reduced the average time for } \\
\text { dealing with construction permits from 410 days } \\
\text { to 320. }\end{array}$ \\
\hline Streamlined procedures. & $\begin{array}{l}\text { Cote d'Ivoire, Croatia, Kazakhstan, Mali, } \\
\text { Mexico, Saudi Arabia, Ukraine }\end{array}$ & $\begin{array}{l}\text { Ukraine cut nine of 31 procedures, reducing time } \\
\text { by one third and cost by 6\%. }\end{array}$ \\
\hline $\begin{array}{l}\text { Adopted new building } \\
\text { regulations. }\end{array}$ & Croatia, Hungary, Kazakhstan, Romania & $\begin{array}{l}\text { Amendments to Romania's construction law and } \\
\text { building regulations cut time by 15 days and cost } \\
\text { by 12\%. }\end{array}$ \\
\hline Reduced fees. & $\begin{array}{l}\text { Burkina Faso, Democratic Republic of Congo, } \\
\text { Rwanda, Vietnam }\end{array}$ & $\begin{array}{l}\text { Vietnam's new registration fee for completed } \\
\text { buildings cut total cost by 43\%. }\end{array}$ \\
\hline $\begin{array}{l}\text { Introduced or improved } \\
\text { one-stop shop. }\end{array}$ & $\begin{array}{l}\text { Kazakhstan, Paraguay, Russian, Indonesia, } \\
\text { Federation, Saudi Arabia }\end{array}$ & $\begin{array}{l}\text { In Paraguay, a new single-window approach in } \\
\text { the municipality cut time from 291 to 179 days. }\end{array}$ \\
\hline $\begin{array}{l}\text { Introduced risk-based } \\
\text { approvals. }\end{array}$ & Kazakhstan, Mali & $\begin{array}{l}\text { Mali’s new simplified environmental impact } \\
\text { assessment for noncomplex commercial } \\
\text { buildings cut time by 9\% and cost by 32.7\%. }\end{array}$ \\
\hline $\begin{array}{l}\text { Improved electronic } \\
\text { platforms or online services. }\end{array}$ & Colombia & $\begin{array}{l}\text { Colombia improved its electronic verification of } \\
\text { prebuilding certificates, which cut one procedure. }\end{array}$ \\
\hline
\end{tabular}

Source: World Bank \& IFC (2013).

In 2009, the local government in Hong Kong SAR (China), as a part of its "Be the Smart Regulator" program, merged eight procedures involving six different agencies and two private utilities through a one-stop shop center. A single window facilitates interaction for customers (World Bank \& IFC, 2013). Globally, 22 economies coordinated agencies involved in approving construction permits through some form of one-stop shop (World Bank \& IFC, 2013). Burkina Faso introduced one-stop shop in 2007 and all building permits issued within two years increased from 209 to 611. Canada streamlined procedures in 2005 and commercial building 
permits issued within two years increased by $24 \%$. Also, Hong Kong SAR (China) introduced one-stop shop in 2008 with 150 permits, just after one year, the total commercial building permits issued increased to 171 .

Lower cost-for builders and regulators. Effective and efficient use of information technology can reduce the regulatory cost of construction. Jurisdictions across the United States are using information technology to increase efficiency. More than 500 of them now use an advanced e-permit processing system. Introduced since 2003, the system has reduced the time that professionals in the construction industry spend on permits by $30 \%$ to $40 \%$.

Greater safety and transparency. Overly, complicated construction rules can also increase opportunities for corruption (World Bank \& IFC, 2013). World Bank Enterprise Survey data show that the share of firms expecting to give gifts in exchange for construction approvals is correlated with the level of complexity and cost of dealing with construction permits (Enterprise Surveys, 2010). According to a survey in 2005 conducted in 15 countries by Transparency International, entrepreneurs perceived construction as one of the most corrupt industries, surpassing arms and defense, oil and gas, real estate, and mining (Kenny, 2007). According to Steer (2006), bribes were positively correlated to the number of business permits a firm must obtain in order to operate legally. Evidence suggested that the level of bribes paid by firms in Indonesia was about $40 \%$ of the taxes firms pay (Kuncoro, 2004).

Greater capacity. More efficient systems colud prepare governments to take advantage of a pickup in construction activity (World Bank, 2013b). Generally speaking, reducing delays benefits more than just builders and owners. A study in the United States estimated that accelerating permit approvals by three months in a 22 months' project cycle could increase construction spending by 5.7\% and property tax revenue for local governments by 16\% (Bureau of Labor Statistics, 2010; Pricewaterhouse Coopers, 2005). In the study of Gete (2014), the costs connected with obtaining building permits and the number of days to acquire those permits, which changed the reaction of macroeconomic variables to interest rate shocks established.

Focusing on results. When regulations are not organized and applied coherently, builders and authorities can become confused about how to proceed. This often leads to delays, uncertainty, and disputes (World Bank \& IFC, 2013). The inefficiencies in the permitting framework also created major obstacles for growing firms according to Steer (2006).

Online in the Middle East, North Africa, and East Asia. Economies in the Middle East and North Africa made the acquisition of construction permits stress-free by introducing online services and electronic platforms. This trend was initiated in the early 1990s by some Gulf Cooperation Council countries (Bahrain, Qatar, Saudi Arabia, and the United Arab Emirates). In Bahrain, where complying with building formalities takes the least time in the region, applicants can download forms, submit applications, and building plans, track the status of their applications, and pay bills—all online. The changes in the region reduced the average permitting duration by 41 days, making the Middle East and North Africa the fastest globally (Ministry of Works, Municipalities Affairs and Urban Planning, 2015).

The Middle East and North Africa were not the only regions where technology was used to make construction permitting more efficient. East Asia and the Pacific, Singapore, and Hong Kong SAR (China) converted their one-stop shops for building permits to online systems in 2008. In Singapore, the Building and Construction Authority provides easy access to relevant information and allows online submission of all paperwork. In Hong Kong SAR (China), while the application process still has to be completed in person, all application forms and zoning maps are now available online (World Bank \& IFC, 2013). 


\section{The Ghanaian Situation of Unauthorized Structural Development}

According to World Bank \& IFC (2013), 60\% to 80\% of building projects in developing economies commenced without the proper permits and approvals. Which confirms Freiku's (2003) article in Ghanaian Chronicle, titled "Kumasi Development Getting Worse, Chaotic", highlighting the poor state of building development in Kumasi Township. Astoundingly, $80 \%$ of buildings in the metropolis are without permits. Also, between 1990 and 2000, only 7.2\% of buildings in the metropolis had permits. This is partly due to the difficulty in the acquisition of lease documents or titles to necessitate the granting of permits.

Lengthy processing durations, lack of information on permit processes, and high cost deter developers from applying for permits (World Bank, 2013b; Steer, 2006). Many developers or people are unaware of laws on housing (Agyeman et al., 2015). Many old and emerging communities have no planning permission. Certain communities have multiple planning schemes, making plan implementation difficult. This is the disturbing building permit state or building development status of Kumasi. What about other towns and cities in the country? The situation may not be far from different (Ghanadistricts, 2006). It is believed that the numerous illegal and indiscriminate erections of various structures and building edifices can be attributed in part to the length of time a building permit application goes through (Moullier, 2009). Some stubborn and impatient developers blatantly ignore or resist development abatement directives citing delays or difficulties in securing the permits to justify their illegal development. Individuals and corporate developers have stories to recount about the level of frustration and cost incurred due to the numerous follow-ups and accompanying delays experienced whilst patiently waiting for the issuance of building permits (Botchway, Afram, \& Ankrah, 2014).

Local authorities have also put forward many justifications for such delays. As a result of the impasse, the 1996 National Building Regulation L. I. 1630 Section 8 (1 and 2) was fashioned out as follows: "Where a person submits an application for a building permit, the District Planning Authority shall notify the applicant within seven days of the receipt of the application and shall within a period of three months thereafter notify the applicant whether the application is granted or refused". It goes on to conclude that "an applicant not informed about the grant or refusal of an application may after the expiry of the three months commence development on the basis that the application is acceptable to the District Planning Authority”. Clearly, this seemly controversial clause in the regulation seeks to introduce checks and balances by putting permit issuing authorities into action to avoid unreasonable delays whilst keeping applicants abreast with any important matter related to each building permit application (Ghanadistricts, 2006; Government of Ghana, 1996; Hammah, 2010). Although this was brightly stated in the L. I. 1630, the implementation has not been effective.

\section{Related Systems}

There have been attempts both locally and internationally to change the procedures used in acquiring building permits. Information Communication Technology (ICT) and Geographic Information Systems (GIS) have been used extensively in this regard to achieve this objective internationally. In the US, some of the states have managed to put application and the processing of building permits on the internet. For instance, the US Census keeps track of all building permits issued to clients from municipalities, county offices, townships, and unincorporated towns. From their website, it is possible to access the database of all issued building permits from any of the jurisdictions in all the 50 states in the US (Census, 2009). Outside experience in the use of ICT in the building permit application and processing are discussed below. 
MyBuildingPermit.com. MyBuildingPermit.com is an easy-to-use permitting portal that makes it possible to apply for, pay for, and receive electrical, low voltage, mechanical, plumbing, and re-roof permits from each of the participating jurisdictions (MyBuildingPermit, 2016).

The census stats. This application provides construction statistics by permit issuing place and by county on new privately-owned residential housing units authorized by building permits. Data items include the number of buildings, units, and construction cost from new privately-owned residential building permits issued. These data are updated monthly (Censtats, 2009).

Permit place. Permit Place manages environment, film, special events, signs, buildings, entitlements, zoning, and conditional use permits nationwide. Permit Place gets you copies of all building permits on file quickly and accurately, for any residential or commercial property in Southern California. Permit Place provides a complete report of the property's construction history as quick as possible. With numerous project managers in the field every day, Permit Place complete research requests quickly and efficiently. With a valid address or parcel number, Permit Place can pull any documents on file within the corresponding jurisdiction's records (PermitPlace, 2016).

Home builders weekly. Home Builders Weekly (HBW) provides complete, accurate, and timely building permit information to their customers in Florida, Georgia, Texas, and now Alabama. Every week, HBW has representatives in Building Departments all over Florida, Georgia, Texas, and Alabama, recording the "Who, What, When and Where” of every single construction permit issued—both residential and commercial (HBW, 2016).

\section{Research Methods}

In providing a framework of review and actions, the following key study principles were applied to the reengineering process:

(1) Gathering and analyzing existing data to get a clear understanding of how the work processes currently operate within permit agencies in Ghana, as well as collect information from other connected agencies.

(2) Visiting of some selected Metropolitan, Municipal, Districts, and Lands Commission offices to obtained stakeholders' qualitative reviews of the existing process to assist in identifying process areas of key customer concern.

(3) Creating process flow charts-a tool that visually displays an entire process in a logical sequence of events from beginning to end was used. Both “As-Is” and "To-Be” process charts were produced in Ghanaian context—which may be seen in the "Reviewed Process" section of this paper. These charts provided a structure for thinking through an often complex process in a simplified manner, which can then be analyzed. Process flow charts were used as the base to ask questions about the process such as: Why? What happens if ...? Do we have to ...? What is the consequence of not doing...? What does this mean? How did that get started? What is the purpose for that? What is the value-added (steps that are relevant/contribute to effectiveness)? What is the non-value added (bottlenecks, barriers, breakdowns, etc.)?

\section{Research Results and Analysis}

\section{Overview of the Building Permit Acquisition Process}

“As-Is”. The first step you need to take to get a building permit in Ghana is to submit an application to the Lands Commission for land title certificate (Government of Ghana, 2008). Before you can get a permit, this 
government agency has to confirm that the land legally belongs to you (Botchway et al., 2014). After the Land Commission has confirmed that the applicants do indeed own the land, the building permit process then begins with the Town and Country Planning Department (TCPD). Stages for the issuance of building permits in Ghana are indicated in Figure 1.

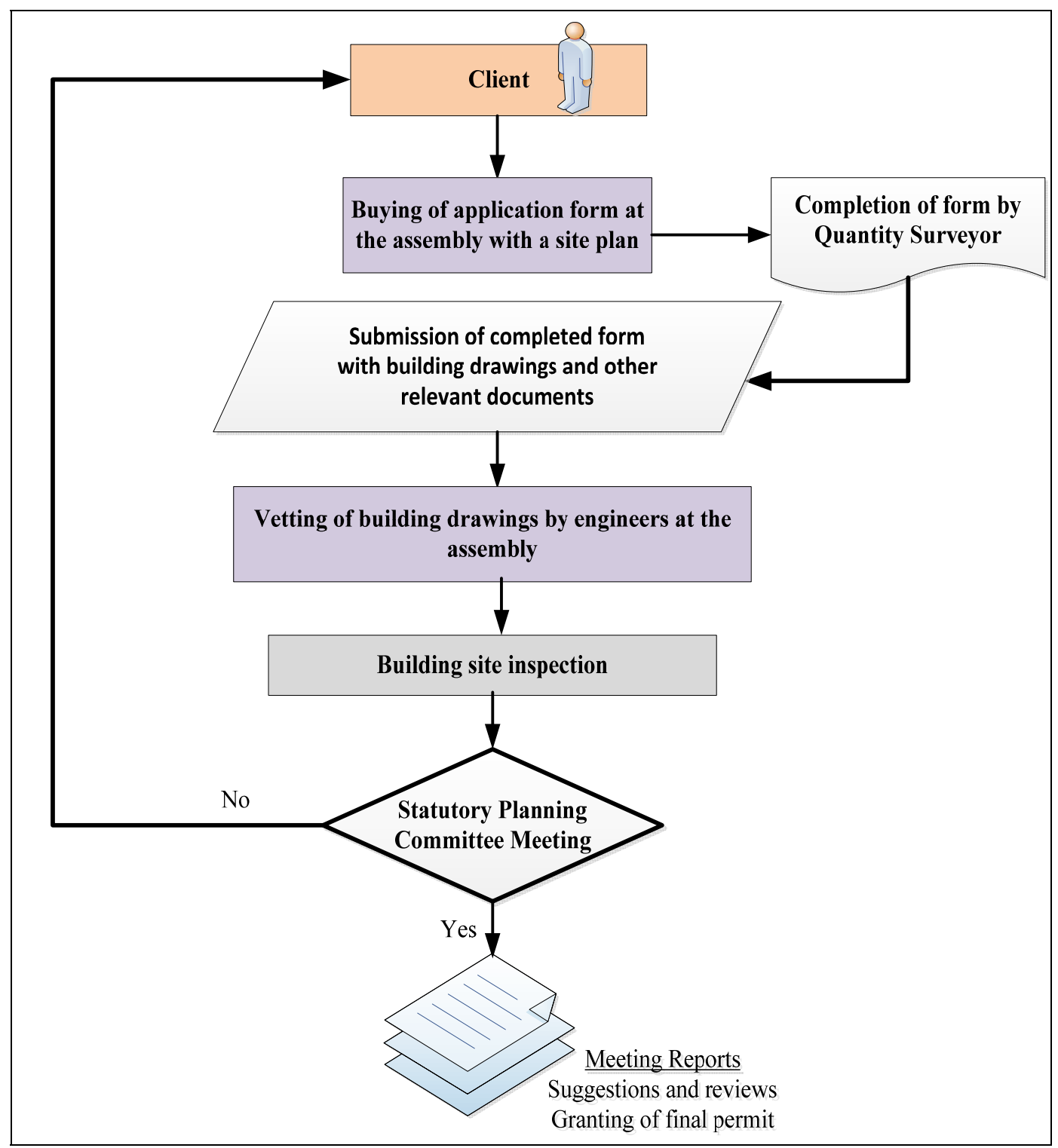

Figure 1. Flow chart showing the current building acquisition procedure in Ghana.

The TCPD will assemble a committee of inspectors to observe the land and analyze the client's building or house plans. If the plans are approved, a recommendation is made to the Statutory Planning Committee (SPC), which is the government agency that will really administer the issuance of the building permit once the documentation has been reviewed (Quartey, 2011).

As shown in Figure 1, the prospective permit client buys an application form at the local authority office (MMDAs) with the site plan of the parcel to be developed. This site plan is usually reproduced from an existing site plan that contains the parcel in question. The application form is then completed by draughtsman (which 
should have been done by a Licensed Quantity Surveyor). The client submits the completed application forms with the building drawings for processing. The documents are vetted by a committee and necessary field inspection carried out by the building inspectors. Also ownership verification of parcel of interest at the Lands Commission is done. If the application passes all these tests, it is then forwarded to the SPC for final granting of the building permit.

However, SPC meets either quarterly or the committee members are called to meet based on the number of applications submitted within two months. If the application fails, the whole process has to be restarted but no notification or feedback will be given to the client. The ownership verification process can also delay the whole process as there is no efficient and modern land record system at the Lands Commission to fast track the search. The client also cannot monitor the progress of the application. The building permit acquisition process is therefore process oriented and therefore does not consider client's satisfaction. Eventually, the client's confidence in the whole process is decreased. Although, LAP has been introduced with the passage into law in the Lands Commission Act 2008 (Act, 767), the mechanical way of doing thing at the various permit issuing agencies is yet to see any makeover. Challenges in the current permit acquisition process can be summarized as follows:

(1) Bureaucratic delays and increased frustration which lead to construction cost growth and loss of value.

(2) Accessible and updatable data for processing permit are difficult.

(3) Lack of co-ordination between the land agencies and the local authorities.

(4) There are no mechanisms to check the validity of some of the documents supplied by the client.

(5) Search for ownership at the Lands Commission can be very cumbersome.

(6) Inadequate number of staff for the field inspection and monitoring.

(7) Lack of modern ways (using ICT) of keeping and retrieving land records at the Lands Commission.

(8) Financial constraints to permit issuing agencies.

(9) Bribery and corruption resulting from the use of intermediaries.

\section{The One-Stop Shop}

“To-Be”. One-stop shop is a data storage bank/unit with various linkages which can be accessed by land agencies and other stakeholders who have the authorization (Forkuo \& Asiedu, 2009). This will be deployed in Geographic Information Systems (GIS) environment with Geodatabase (Spatial and Non-Spatial) having the following themes: layout scheme (parcel information), land use and land cover, land area, topographical maps, cadastral plans, geodetic control network, soil maps, and other relevant field information. In the one-stop shop, institutions such as the Town and Country Planning, Geomatic Department (Survey Department), Office of the Administrator of Stool Lands (OASL), Lands Commission, Municipal Assembly, Environmental Protection Agency (EPA), etc. will be hooked to a central data storage unit as shown in Figure 2. That is, an officer in any of the above institutions can have access to all land information and other related matters without physically moving from one office to another. Thus, a simultaneous permit reviews through computer linkage.

Take a parcel in Abesim (Sunyani Municipality) for example, the one-stop shop will have a unique identifier, title holder's name, topographic information of the land, purpose of demarcation, geodetic network information, geotechnical information, land area, etc., as first-hand information to the Senior Officers involved in issuing the building permits. Therefore, instead of files (hard copies) moving from one institution to another, soft copies will rather be used. 


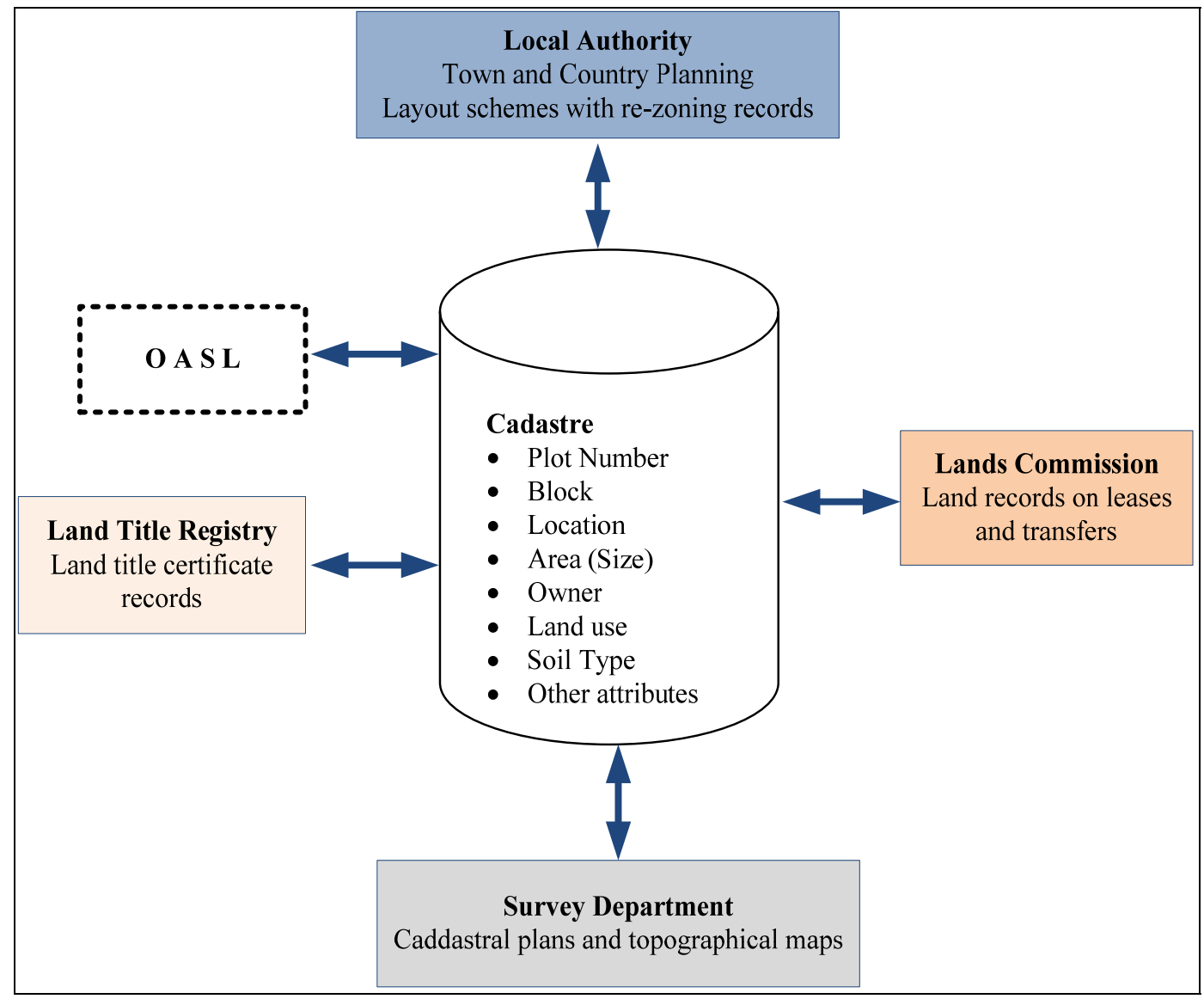

Figure 2. Proposed data exchange between the land agencies.

\section{Website Client Services}

At the homepage of the assembly's website, clients can fill, upload, or download building permit application forms in portable document format (pdf), and Microsoft word (doc. or docx.) formats. Attach relevant documents and carry out required payments using bankers draft, electronic visa (various cards), E-Zwich, etc. Applicants can also download Bill of Quantities for expert to fill, upload their site plans and various building drawings to the intended institutions. They can also monitor the progress of their applications, way-in all information relating to building permits in Ghana, access statistics of all successful and unsuccessful permits, subscribe to various information on permits updates, receive mails on receipts of all payments, relevant documents, application forms, etc., and progress reports of application and answers to questions relating to all building permits in Ghana. The revised process is shown in Figure 3.

There will be other online services for applicants and other stakeholders like webmap and web feature services. These services will help applicants to check the spatial accuracy of their site plans and the surrounding developments.

\section{Permit Processing Phase I (Verification Phase)}

At the front desk, verification of all documents submitted by the applicant is carried out or vetted. Rightful ownership of the land is also verified. Since the central database (cadaster) has information such as land use, land cover and title, and all other relevant field informations which are linked to the Lands Commission, verification of land owner will be simple and less cumbersome. In addition, short videos can be attached to the 
land information for clarity and surety of the vetting officer. If the application passes successfully through phase I, a provisional/development permit can be granted pending the issuing of a final permit. However, if an application fails to pass through this process, the applicant has to restart the whole permit process again from the front desk.

\section{Permit Processing Phase II (Final Granting of Permit)}

Members of the Statutory Committee get together to decide on whether to grant or not grant the applicant's quest for the building permit. Their final decision determines the fate of the application based on the health and safety implication of the intended building on the environment (examples: flora and fauna).

These meetings are done quarterly, therefore any amendment in the Building Regulations (L. I. 1630) aimed at increasing the frequency of meetings (say one per month) will go a long way to reduce some of the delays in the system. Thus, because if all other processes are done in the shortest possible time and the final decision delays the whole re-engineered process will be a failure. If an applicant fails to meet all the requirements in this stage the application will have to go back to the verification stage to restart the process again. Otherwise, a publication is carried out on the assembly's website and download link sent to the permit applicant.

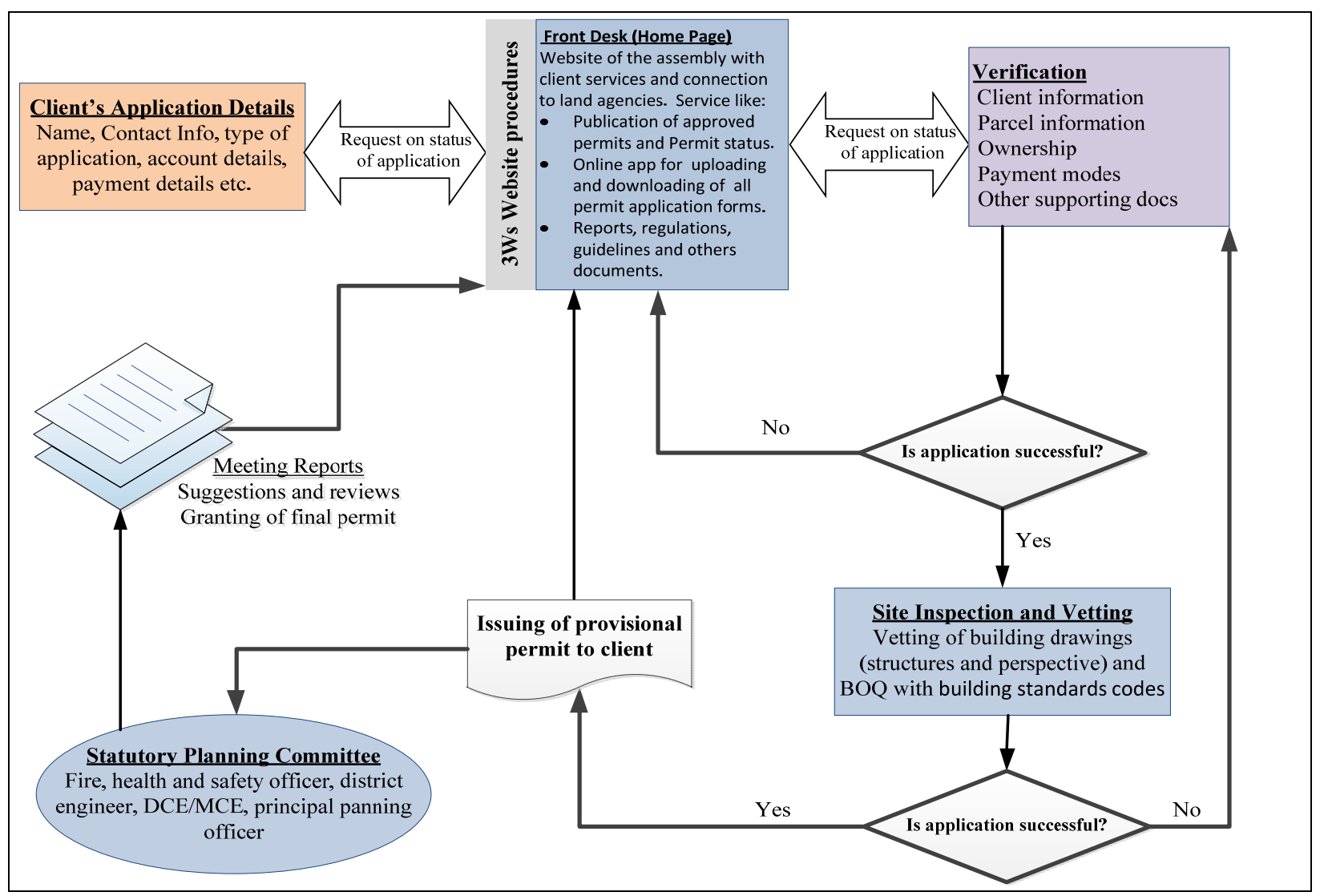

Figure 3. Flow chart showing the re-engineered building permits processing procedures using ICT.

\section{SWOT Analyses of the Reviewed System}

The SWOT (strengths, weaknesses, opportunities, and threats) analyses of the reviewed system are as follows: 


\section{Strengths}

(1) Majority of Ghanaians desire to build speedily in a stress free environment.

(2) Lowering cost of ICT ware and technological advancements.

\section{Weaknesses}

(1) Reluctance of cities authorities or local authorities to invest in ICT.

(2) Inconsistent spatial data.

(3) Land disputes, land tenure system, and land acquisition problems.

\section{Opportunities}

(1) The desire to computerize some operations in the country is increasing such as the School Placement System, CAGD (E-payslips), WAEC online registration and checking of results, clearing of cheques and goods electronically (E-commerce), E-voting, etc.

(2) Lessons from operating systems such as mybuildingpermit.com, permitplace.com, etc. can help to fine-tune the proposed system implementation.

\section{Threats}

(1) Likelihood of siting new companies in certain areas has the tendency of attracting people to a particular locality, aggravating the current problem of rural-urban migration, intensifying the economic hardships, and increasing the housing deficit in the country.

(2) Corruption on the part of the personnel involved in the field inspection and monitoring can sabotage the system.

\section{Conclusions}

A central database management system (one-stop shop) connecting all the agencies involved in the building permit processing where any application could be worked on by the appropriate agency has been proposed. The proposed umbrella body known as the data exchange unit will also house all the agencies involved in permit process. Furthermore, the existing permit acquisition process has been reengineered to facilitate the issuance of building permits. The SWOT analysis of the revised permit acquisition process indicated a great future prospect.

\section{References}

Agyeman, S., Asiedu, S. B., \& Abeka, H. (2015). Clients' knowledge on building permit acquisition process-The case of Sunyani East Municipal Assembly. Developing Country Studies, 5(18), 8-20.

Botchway, E., Afram, S. O., \& Ankrah, J. (2014). Building permit acquisition in Ghana: The situation in Kumasi. International Institute of Science, Technology and Education (IISTE), 4(20), 11-22.

Bureau of Labor Statistics. (2010). Occupational employment statistics (OES). United State Department of Labor. Retrieved from http://www.bls.gov/oes/

Census. (2009). Censtats web site. Retrieved from http:/www.censtats.census.gov/bldg/bldgprmt.shtml

Enterprise Surveys. (2010). Top 10 business environment constraints. Washington, D.C.: World Bank. Retrieved from http://www.enterprisesurveys.org

Forkuo, E. K., \& Asiedu, S. B. (2009). Developing a one-stop shop model for integrated land information management. Journal of Science and Technology, 29(3), 114-125.

Freiku, S. R. (2003). Ghana: Kumasi's development getting worse, chaotic. Report Published for Local Government and Assembly Deliberation. Accra: Ghana News Agency (GNA).

Freiku, S. R. (2009). Town and Country Department to issue building permits in three months. Accra, Ghana: Agency Ghana News. Retrieved from http://www.ghanabusinessnews.com/2009/06/21/town-country-department-to-issue-building-permits-in-three-months/ 
Gete, P. (2014). Dealing with construction permits, interest rate shocks and macroeconomic dynamics. Proceedings from Doing Business (DB) Conference, pp. 1-2.

Ghanadistricts. (2006). Building Permits (1): Public concerns the assemblies must address. A Public-Private Partnership Programme between Ministry of Local Government and Rural Development. Accra, Ghana: Media, Development and Maks Publications \& Services. Retrieved from http://www.ghanadistricts.com/home/?_=49\&sa=4639

Government of Ghana. (1996). Building regulations of Ghana LI 1630. Accra: Ministry of Works and Housing.

Government of Ghana. (2008). Lands Commission Act, (Act 767). Accra: Ministry of Lands and Forestry.

Hammah, N. K. (2010). Re-echoing building permits. Permit Journals to Revamp Public Consciousness. Retrieved from http://wavesint.org/?s=re-echoing+building+permitsitle

HBW. (2016). Home builders weekly (HBW) web site. Request a free sample building permit report. Retrieved from http://www.hbweekly.com

Kenny, C. (2007). Construction, corruption, and developing countries. World Bank Policy Research Working Paper 4271. Washington, D.C., USA: Word Bank. Retrieved from http://econ.worldbank.org

Kpamma, E. Z., \& Adjei-Kumi, T. (2013). Construction permits and flow of projects within the Sunyani Municipality, Ghana. Proceedings from International Group on Lean Construction (IGLC), pp. 257-266. Fortaleza, Brazil: IGLC.

Kuncoro, A. (2004). Bribery in Indonesia: Some evidence from micro-level data. Bulletin of Indonesian Economic Studies, 40(3), 329-354.

Ministry of Works, Municipalities Affairs and Urban Planning. (2015). Building permit. Manama, Kingdom of Bahrain. Retrieved from http://www.municipality.gov.bh/

Moullier, T. (2009). Reforming building permits: Why is it important and what can IFC really do? Washington, D.C.: International Finance Corporation.

MyBuildingPermit. (2016). Mybuildingpermit web site. Permit packets. (eCityGov alliances, Washington, D.C.). Retrieved from https://epermit.mybuildingpermit.com

Oppong, R. A., \& Yeboah, E. (2013). Empirical examinations of conflicts and contradictions in architecture, land and suburban sprawl: The case of Tamale, Ghana. Journal of Science and Technology, 33(1), 92-104.

PermitPlace. (2016). Permitplace web site. Building Permit and Planning Services. Retrieved from http://www.permitplace.com/index.php/Permit-Blog/Dorchester-County-Maryland-Permit-Report-for-January-2016.html

Pricewaterhouse Coopers. (2005). Economic impacts of accelerating permit processes on local development and government revenues. Washington, D.C.: American Institute of Architect.

Quartey, R. Q. (2011). Performance audit report of the Auditor General on the management of building permits at Ga East Municipal Assembly. Accra: Parliament of Ghana.

Steer, L. (2006). Business licensing and one-stop shops in Indonesia. The Asia Foundation. Jakarta: Economic Programs.

World Bank. (2013a). Good practices for construction regulation and enforcement reform: Guidelines for reformers. Investment Climate Report number: 77100, Working Paper. Washington, D.C.: World Bank Group. Retrieved from http://documents.worldbank.org

World Bank. (2013b). Doing business 2013: Smarter regulations for small and medium-size enterprises. Creative Commons Attribution CC BY 3.0. Washington, D.C.: World Bank Group.

World Bank \& IFC. (2013). Dealing with construction permits. Washington, D.C.: World Bank Group and International Finance Corporation. Retrieved from http://www.doingbusiness.org/data/exploretopics/starting-a-business 